\title{
Special Measures for Crime Unit Police Resort Kudus in Law Enforcement of Infringement Currency Crime
}

\author{
Danail Arifin ${ }^{1}$ and Maryanto ${ }^{2}$
}

Abstract. This study aims to 1) special crimes unit Efforts to combat the crime of counterfeiting currency in the police resort Kudus; 2 ) The implementation of the inhibiting factors against the crime of counterfeiting currency in police resort Kudus; 3) The solution in overcoming barriers to enforcement against the crime of counterfeiting currency Police resort Kudus

The results showed that Significantly, the circulation of counterfeit money in Kudus Regency has experienced a dramatic decline in the period 2016 to 2017. It certainly shows that the performance of the police improved and further strengthen the Police in achieving the common goal of protecting the public. Role in preventing the circulation of counterfeit money by providing guidance and counseling especially those of the general public and institutions engaged in financial cooperation with Bank Indonesia. For problems counseling time and place, it is determined from the results of the evaluation in areas that are found counterfeit money circulation. Factors hindering the implementation of the Crime Against Counterfeiting Currency Police resort Kudus Already a strong determination of the Kudus Police to combat the crime of counterfeit money in circulation to the brain from the source or the manufacturer and distributor of counterfeit money because the circulation of counterfeit money has been very disturbing society and causing huge losses for the society and the state. Keywords: Crime; Law Enforcement; Counterfeit Currency.

\section{Introduction}

Money is an object that is used in such a way as a means of transaction as well as legal tender, money is also a symbol of the state which became an integral tool, or it can also be a means of economic domination or occupation by a country to other countries. The money consists of coins and banknotes. Coin is in the form of money consisting of metal materials such as gold, copper, silver, and so forth, whereas paper money is money that is made of a sheet of paper.

Paper money is divided into two (2) types, ie banknotes and banknote State Bank. State's banknotes are banknotes issued by the State Bank and banknotes are banknotes issued by a bank designated by the government. Bank appointed by the government to create and issue banknotes is Bank Indonesia.

The function of money, namely: ${ }^{3}$

- As a Compute Unit;

- As the Transaction Tools

\footnotetext{
${ }^{1}$ Student of Master of Law, Universitas Islam Sultan Agung Semarang and Members of the Indonesian National Police (Polri), Email: arifin72030@gmail.com

${ }^{2}$ Faculty of Law Universitas Islam Sultan Agung

${ }^{3}$ Boediono, Ekonomi Moneter. BPFE. Yogyakarta, 1990, p. 10
} 
- As Depositary Value

- Payment Standards in the Future

Money is a tool that is used as a tool or as a means of payment transactions in everyday life many forged or imitated resembles real currency and widely circulated in the community. Counterfeit banknotes have done especially since the first time the paper money used as legal tender. How well the banknote counterfeiting techniques starts with simple ways to the way through modern technology used on today. Counterfeiting and circulation of money is generally carried out jointly by the perpetrators of counterfeiting with a goal and a purpose.

The purpose and intent of counterfeiting done initially to enrich themselves, or to get something that is expected to pay to use the counterfeit money. Given the importance of the meaning and value for money in various aspects of human life, counterfeit money can also be used in order to stifle the economy of a country.

Criminal act of counterfeiting which lately quite unsettling among the public at large, the modes they use no less elaborate apparatus they use can be classified as very modern in which only those who have thought of a genius who is able to use it, they sometimes capable of producing counterfeit money in a short time period by the number of billions of rupiah, and the results are almost similar to real money, therefore this issue should not we consider a simple either by the government, law enforcement and the community must seriously address this issue, because counterfeiting crimes can enter the broad scope

Criminal acts of counterfeiting are not foreign to our ears. Police officers Kudus, Central Java, arrest five dealers of counterfeit money denominations 100,000 (one hundred thousand rupiah) and any evidence denomination of 100,000 (one hundred thousand rupiah) 60 (sixty) pieces. disclosure of the case originated from information society that is no circulation of fake money. Base such information, then the police from the police Dawe managed to arrest an offender named Eko Purwanto village residents Klumpit, District Gebog, Kudus, and Aswati, village residents Ngembal Kulon, District Jati, Kudus, Market Dawe, District Dawe, Kudus, March 5, 2018. From the statements of the two actors, then officers re-arrested three other actors, namely Risky Klumpit village residents, Sumardi, villagers Singocandi, the Kudus City, and Suripan Jetak Village residents, District Kaliwungu, Kudus. The fifth suspect who was arrested on the role of dealers as well as dealers and sellers of counterfeit money. While the amount of counterfeit money which successfully secured the officers of the five suspects were 60 (sixty) bills 100,000 (one hundred thousand rupiahs) or equivalent Rp.6.000.000 (six million rupiah). The amount of money that has been circulating in the community is estimated at Rp.20.000.000 (twenty million rupiahs). Fractional counterfeit currency 100,000 (one hundred thousand rupiah) are obtained from a person of Surabaya. "Every 1,000,000 (one million) the original money to get 30 (thirty) pieces of counterfeit currency denominations 100,000 (one hundred thousand rupiah) Of the five suspects, Suripan is a supplier for the fourth suspect counterfeit sharing system. ${ }^{4}$

\footnotetext{
${ }^{4}$ Preriset in the Kudus Police 28 September 2018
} 
Based on the problems described above, the authors are interested in doing research in the form of legal writing and discuss it in the form of a thesis with the title "Special Measures For Crime Unit Police Resort Kudus In Law Enforcement Of Infringement Currency Crime".

\section{Research Methods}

The method used is qualitative analysis, namely data obtained through fieldwork and research literature then arranged systematically, and then analyzed qualitatively to achieve clarity issues to be discussed. The data is then analyzed using a theoretical and interpretive positive law which has been poured and then deductively conclude to address existing problems. ${ }^{5}$

\section{Results And Discussion}

\subsection{Efforts Special Crimes Unit In Combating The Crime Of Counterfeiting Currency In The Police Resort Kudus}

Significantly, the circulation of counterfeit money in Kudus Regency has experienced a dramatic decline in the period 2016 to 2017. It certainly shows that the performance of the police improved and further strengthen the Police in achieving the common goal of protecting the public. The efforts made by the Kudus Police concreted in the form of a working team within an organizational structure that will allow for the realization of basic tasks of Police.

Keep in mind that the Kudus Police consists of several functional position that its formation by the Decree of the Chief of Police. Of the existing functional position, in this case I want to examine the actions / efforts made by the police in preventing and combating counterfeiting and circulation of counterfeit money.

Specific Crime Unit In Kudus Police organizational structure, Sat Reskrim Police is the main executive element that is under the Chief of Police. In the organizational structure of the Kudus Sat Reskrim Police is implementing elements of the basic tasks under the Chief of Police. Sat led by Invisible Criminal Criminal responsible to the Chief of Police and the execution of daily tasks under the control Wakapolres. Sat Reskrim charge of carrying out the inquiry, investigation, and control of criminal investigations, including the identification and forensic laboratory field. In performing these duties, Sat Reskrim the following functions:

- Technical guidance on administrative inquiries and investigations as well as the identification and forensic laboratory field;

- Services and special protection to adolescents, children, and women both as perpetrators and victims in accordance with the provisions of the legislation in force;

- The identification for the purpose of investigation and public services;

- Analyzing cases and their management, and assess the effectiveness of the implementation of tasks Satreskrim;

\footnotetext{
${ }^{5}$ Ibid, p.119
} 
- Supervision of criminal investigations conducted by investigators in the unit Satreskrim Criminal Police and the Police;

- Guidance, coordination and supervision of investigators both in operational and administrative investigation in accordance with the provisions of the legislation in force;

- Inquiry and investigation of criminal offenses generally and specifically, among other economic crimes, corruption, and certain criminal acts in the area of the police station.

Criminal visible in carrying out his duty is assisted by:

- Head of Operational Development abbreviated (Kaur Binops);

- Head of the Administrative Affairs, Administration and abbreviated (Kaur Mintu);

- Head of Identification abbreviated (Kaur Ident); and

- Head of Unit consisting of a maximum of 6 units.

- In connection with the precautionary measures taken by the police, based on interviews with Mr. Iptu Cipto as KBO Reskrim/Criminal Police Inspector", "We took charge of preventive actions circulation counterfeit currency with the guidance and counseling of course, we cooperate with Binmas Sat and Bank Indonesia. To target the general public and officials in the field of finance, such as bank officers, treasurers, cashiers, it is our priority because they are the one who played an active role will recognize counterfeit currency. Provide knowledge and increase public awareness of the crime of counterfeiting money and its circulation and the extension is not only held by the police, but it could be held by Bank Indonesia, as well as the general public. As for special cooperation between the Police and the Bank Indonesia, that if there are reports of counterfeit money found by the commercial banks, it will be made an official report submission of the special, which shall promptly we report it to the Bank Indonesia for the requested clarification in order to help the police in the investigation" in this case prevention preventive.

- Role in preventing the circulation of counterfeit currency by giving guidance and counseling especially those of the general public and institutions engaged in financial cooperation with Bank Indonesia. For problems counseling time and place, it is determined from the results of the evaluation in many areas discovered the circulation of counterfeit currency.

\subsection{Factors Inhibiting The Implementation Of The Offenses Of Counterfeiting Currency Police Resort Kudus}

Already a strong determination of the Kudus Police to combat the crime of counterfeit money in circulation to the brain from the source or the manufacturer and distributor of counterfeit money because the circulation of counterfeit money has been very disturbing society and causing huge losses for the society and the state. Has done prevention and control efforts against all forms of crime counterfeiting that in making such efforts, the police encountered some obstacles that can impede their performance.

\footnotetext{
${ }^{6}$ Interview of the KBO Reskrim Polres Kudus Iptu Cipto On Date December 18, 2018
} 
Furthermore, the barriers to the eradication measures, yes because the network dealers are very closed and very neatly kept us trouble, still there are people who are less concerned about the education counseling about the circulation of counterfeit money do the police and Bank Indonesia, People are still afraid to report about finding counterfeit money. it can be seen that the internal factors and external factors that hinder the police in their duty to prevent and control the circulation of counterfeit money:

- Barriers to Preventive / Prevention of Internal Factors:, lack of facilities and infrastructure.

Facilities and infrastructure are referred to here is the lack of operational funds and lack of personnel members of the Police. Police have constraints in the problems due to the funding budgeted funds are used to create banners, billboards, and banners and also to create an ad in a radio broadcast that the funds will be depleted. Therefore, operational funds were quickly depleted, it takes time to reestablish the operational funds that would impede the implementation of police tasks. Insufficient number of police personnel led to execution of his duty to be not optimal because of the number of police personnel are not balanced by the number of residents in the district of Kudus growing and more and more so that would impede the implementation of police tasks.

- External factors: Lack of enthusiasm and participation of the community. In coaching and counseling activities carried out by the Police regarding counterfeit money, people are not so enthusiastic. Could be because people are more enthusiastic about the issues of drugs and the elimination of domestic violence and can be due to busy people in their work so that the lack of participation in the activities of coaching and counseling.

Barriers Repressive / Combating the criminal counterfeit money collected in the syndicate organized, discreet, and has a high mobility are usually the making of counterfeit money is done in rented houses and moved around the place to remove any trace that would be very difficult for officers police combating it.

\subsection{Solutions To Overcome Barriers To Enforcing The Law Against The Crime Of Counterfeiting Currency Police Resort Kudus}

It takes active participation and coordination between the Banking, communities, and Bank Indonesia with the police to prevent and control the circulation of counterfeit money by immediately reporting any findings of counterfeit money to the Police or the nearest to the local Bank Indonesia to clarify the money of doubtful authenticity or counterfeit money found, This will greatly assist the police in their efforts to investigate thoroughly to eradicate the crime of counterfeiting.

Bank as one of the central circulation of money, have a considerable role in preventing the circulation of counterfeit money. Often there are usually counterfeit money real money tucked among bank customers will be deposited to the bank. Banks should always check the authenticity of the money it receives, so that all banks have the means of detecting the authenticity of money and bank officers provided the ability to check real money or of doubtful authenticity or called sorting manually. Contribution 
in preventing the circulation of counterfeit money is to report and make any findings Submission of the Minutes of doubtful authenticity money obtained from the customer to the Bank Indonesia to demand clarification of authenticity if the money is fake or not fake.

Commercial banks, private banks and state banks in urban areas up to the area of the District, the cashier of these banks have to check one by one the money he received because often the cashier find the money of doubtful authenticity or counterfeit money from the deposit of society / customers that are required to report to the authenticity of the clarification request to Bank Indonesia.

Basically, people who already understand about 3D (Seen, Touched, overlooked) either through socialization held by the police or the Bank Indonesia as well as through posters, banners, billboards, banners information counterfeit money is distributed, if people find the money apocryphal certainly be responsive and required to report to the authenticity of the clarification request to Bank Indonesia.

Based on interviews that have been made by Mr. Asral Prevention Division Currency of Bank Indonesia, ${ }^{7}$ about factors that encourage police to prevent and cope with the circulation of counterfeit currency that is disclosed as follows: There is a special coordination between the central bank, banking, and the community in helping the police to prevent and combat the circulation of counterfeit money in the Spirit is to make a report each related to the money of doubtful authenticity to our clarification authenticity with special equipment that we have. Regarding reporting, there is a procedure. Once clarified, we will inform you whether the money is genuine or fake. If genuine, we return to the complainant with a particular letter, and if false it will be submitted to the Police by including the Notice of Inspection and Bank Indonesia is a party that has the most important role in determining real or fake money that can help police combat the circulation of counterfeit money.

Bank as one of the central circulation of money, have a considerable role in preventing the circulation of counterfeit currency. Often there are usually counterfeit currency were tucked among bank customers real money to be paid to the bank. Banks should always check the authenticity of the money it receives, so that all banks have the means of detecting the authenticity of money and bank officers provided the ability to check real money or of doubtful authenticity or called sorting manually. Contribution in preventing the circulation of counterfeit money is to report and make any findings Submission of the Minutes of doubtful authenticity money obtained from the customer to the Bank Indonesia to demand clarification of authenticity if the money is fake or not fake.

\section{Closing}

\subsection{Conclusion}

- Significantly, the circulation of counterfeit money in Kudus Regency has experienced a dramatic decline in the period 2016 to 2017. It certainly shows that

\footnotetext{
${ }^{7}$ Interview Prevention Division Currencies Bank Indonesia Mr. Asral, On Date December 20, 2018
} 
the performance of the police improved and further strengthen the Police in achieving the common goal of protecting the public. The efforts made by the Kudus Police concreted in the form of a working team within an organizational structure that will allow for the realization of basic tasks of Police.

- Role in preventing the circulation of counterfeit money by providing guidance and counseling especially those of the general public and institutions engaged in financial cooperation with Bank Indonesia. For problems counseling time and place, it is determined from the results of the evaluation in areas that are found counterfeit money circulation. With the training and development undertaken by Sat Reskrim and Sat Binmas, it is expected to raise public awareness in order to always be alert to the money she received to characterize real money with counterfeit and immediately report to the police if people do not accidentally get money the apocryphal and knowing syndicate counterfeit money circulation.

- Factors hindering the implementation of the Crime Against Counterfeiting Currency Territory police resort Kudus already a strong determination of the Kudus Police to combat the crime of counterfeit money in circulation to the brain from the source or the manufacturer and distributor of counterfeit money because the circulation of counterfeit money has been very disturbing society and causing huge losses for the society and the state. Has done prevention and control efforts against all forms of crime counterfeiting that in making such efforts, the police encountered some obstacles that can impede their performance.

It takes active participation and coordination between the Banking, communities, and Bank Indonesia with the police to prevent and control the circulation of counterfeit money by immediately reporting any findings of counterfeit money to the Police or the nearest to the local Bank Indonesia to clarify the money of doubtful authenticity or counterfeit money found,. This will greatly assist the police in their efforts to investigate thoroughly to eradicate the crime of counterfeiting.

\subsection{Suggestion}

- The government should be more assertive, committed, and consistent with the rules that have been created to combat the crime of counterfeiting. The makers and dealers of counterfeit money should be given punishment as severe in order to provide a deterrent effect.

- Community should support Bank Indonesia in tackling counterfeit money circulation in Indonesia by reporting to the police or Bank Indonesia, as it is the duty of all the peoples of Indonesia to secure rupiah of the crime of counterfeiting.

- Bank Indonesia as the only institution entitled to issue and circulate the money should be thinking of ways to create rupiah either paper or metal having perfect quality and made with the use of the latest technology making it difficult to forge.

- Bank Indonesia and related institutions take steps to prevent the circulation of counterfeit money as early as possible by providing knowledge to the students about the characteristics of the authenticity of the rupiah through awareness / education and distribution of brochures to schools 


\section{Bibliography}

[1] Andi Hamzah, 2001, Bunga Rampai Hukum Pidana dan Acara Pidana, Jakarta, Ghalia Indonesia

[2] Bambang Purnomo dan Arun Sakidjo, 2003, Seri Hukum Pidana 1, Ghalia Indonesia, Jakarta

[3] Bambang Sugugono,2003, Metode Penelitian hukum, PT Raja Grafindo Persada, Jakarta

[4] Roeslan saleh, 1983,Perbuatan Pidana Dan Pertanggungjawaban Pidana, Jakarta

[5] Soerjono Soekamto, 1987, Pengantar Peneltian Hukum, Universitas Indonesia Press, Jakarta.

[6] Soejono soekanto, 1993, Faktor-Faktor Yang Mempengaruhi Penegakan Hukum, Raja Grafindo Persada, Jakarta 